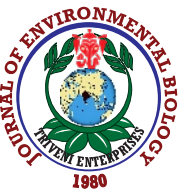

\title{
Effect of soil incubation with organics on rhizosphere and bulk soil properties, root and alkaloid content of Withania somnifera $L$. Dunal and its performance in Jammu Division
}

\author{
R. Gupta ${ }^{1 *}$, Sanjay-Swami ${ }^{2}$ and Z. Banoo ${ }^{1}$ \\ ${ }^{1}$ Division of Soil Science and Agricultural Chemistry, SKUAST-J, Chatha-180009, Jammu \\ ${ }^{2}$ School of Natural Resource Management, College of Post Graduate Studies in Agricultural Sciences, CAU, Umiam (Barapani)-793 103, India \\ *Corresponding Author Email : renugupta2781975@gmail.com
}

Paper received: 13.06 .2020

Revised received: 03.10 .2020

Accepted: 30.10 .2020

\begin{abstract}
Aim: To study the effect of soil incubation with organics on rhizosphere and bulk soil properties, biomass and alkaloid content of Withania somnifera as well as plant performance in soil of subtropical and intermediate zones of Jammu division.

Methodology : The pot experiment of Withania somnifera consisted of 11 treatments laid in randomized block design in triplicate. Sampling was done at various days of soil incubation with organics viz. 30,60, 120 and 180. The plant performance was studied at vegetative and seed maturity stages. In field experiment, the plant performance was studied in soils of subtropical and intermediate zones of Jammu division.
\end{abstract}

Results: The soil properties, root and alkaloid content were found to be maximum in PSB + Azospirillum +Azotobacter+ F.Y.M 20t ha ${ }^{-1}+$ Vermicompost $5 t$ ha' ${ }^{-1}$ treatment. The effect of organics on rhizosphere and bulk soil properties at days of soil incubation yielded superior results with respect to soil health, biomass and alkaloid content in Withania somnifera.

Interpretation: The study indicated that soils of Jammu division is well suited for the cultivation of $W$. somnifera. The study provided framework to develop integrated plant nutrient management strategies in the subtropical region of this high value crop.

Key words: Alkaloid content, Rhizosphere, Vermicompost, Withania somnifera

The soil properties, root and alkaloid content (\%) was found maximum at $T_{10}$ PSB+Azospirillum+Azotobacter+F.Y.M 20t ha ${ }^{-1}+$ Vermicompost $5 \mathrm{t} \mathrm{ha}^{-1}$ treatment at $30,60,90$ and $120 \mathrm{DSI}$. The change was prominent and higher in rhizosphere than bulk soil in all the treatments. Different combinations of organics showed pronounced effect as compared to sole application alone and control in increasing the organic carbon, available nitrogen, phosphorous and potassium $\left(\mathrm{mg} \mathrm{kg}^{-1}\right.$ ) content. Dry biomass ( $\mathrm{g}$ plant $\left.{ }^{1}\right)$, dry root yield $\left(\mathrm{g} \mathrm{plant}^{-1}\right)$ and alkaloids content(\%) increased significantly at seed maturity stage as compared to vegetative stage in all treatments

Pot study

Application of organics improved soil health, biomass and alkaloid content (\%)in Withania somnifera
Dry biomass $\left(\mathrm{g}\right.$ plant $\left.{ }^{-1}\right)$, dry root yield $\left(\mathrm{g}\right.$ plant $\left.{ }^{-1}\right)$ and alkaloids content(\%) of Withania somnifera increased significantly at seed maturity stage as compared to vegetative stage and was higher in Jammu soils followed by Kathua in sub tropical zone and least was recorded in Rajouri in intermediate zone.

\section{Field Study}

The study indicated that soils of Jammu division is well suited for the cultivation of $W$. somnifera

How to cite : Gupta, R., Sanjay-Swami and Z. Banoo: Effect of soil incubation with organics on rhizosphere and bulk soil properties, root and alkaloid content of Withania somnifera L. Dunal and its performance in Jammu Division. J. Environ. Biol., 41, 1632-1640 (2020). 


\section{Introduction}

The portion of soil immediately surrounding the plant roots is termed as rhizosphere (Brink, 2016) and is significantly different from the adjacent bulk soil due to accumulation or depletion of nutrients, release of organic compounds and considerable high microbial density which in alters the physical, chemical and biological properties of the near root environment (Fageria and Stone, 2006; Dessaux et al., 2016). Root exudation plays a pivotal role in determining the rhizosphere microbial population (Bakker et al., 2013; Erktan et al., 2018). The magnitude of changes greatly depends on the initial soil characteristics and genotypes (Barber, 1974; Rovira and Davies, 1974).

Organic application increases nutrient status, microbial activity and productive potential of soil while the use of only chemical fertilisers in the cropping system result in poor microbial activity and productive potential of soil (Kang et al., 2005; Bargaz et al., 2018) and improvement of quality in medicinal and aromatic plants (Khan et al., 2015). Certified medicinal herbs which are eco-friendly and free off synthetic chemicals are in great demand (Khan et al., 2015). Withania somnifera (Ashwagandha) is cultivated specifically for its root which has medicinal and commercial value due to the presence of steroidal alkaloids and steroidal lactones in a class of constituents called withanolides. (Gupta et al.,1996; Krutika et al., 2016). They have anticancer, anti stress, anti-inflammatory, CNS depressant, hepatoprotective and immunomodulatory properties (Dar et al., 2016) In worldwide market, ashwagandha has recently acquired considerable significance and having tremendous marketing potential owing to demand of its roots to the tune of 7000 tons and estimated production of 1500 tonnes (Umadevi et al., 2012). Considering the economic importance of ashwagandha in national and international markets and possible environmental benefits, organic nutrient management is the need of the hour (Chaudhary et al., 2017). In view of the above, the objective of the present study was to evaluate the effect of soil incubation with organics on rhizosphere and bulk soil properties, dry biomass ( $\left.\mathrm{g} \mathrm{plant}^{-1}\right)$, dry root yield $\left(\mathrm{g} \mathrm{plant}^{-1}\right)$ and alkaloid content $(\%)$ in Withania somnifera growing soils and also its performance in soils of Jammu Division.

\section{Materials and Methods}

In $1^{\text {st }}$ set of experiment, one month old seedlings were transplanted to earthen pots each filled with garden soil, sand and farmyard manure in ratio of 5:3:2 ratio. The experiment comprised of eleven treatments as : $\mathrm{T}_{0}$-Control; $\mathrm{T}_{1}$-PSB; $\mathrm{T}_{2}$-Azospirillum; $\mathrm{T}_{3}$ Azotobacter, $\mathrm{T}_{4}-\mathrm{PSB}+$ Azospirillum + Azotobacter, $\mathrm{T}_{5}$ - F.Y.M-15t ha $^{-1} ; \mathrm{T}_{6}$ - F.Y.M $20 \mathrm{t} \mathrm{ha}^{-1} ; \mathrm{T}_{7}$ - Vermicompost - $3 \mathrm{t} \mathrm{ha}^{-1} ; \mathrm{T}_{8}-$ Vermicompost-5 t ha ${ }^{-1} ; \mathrm{T}_{9}-P S B+$ Azospirillum+Azotobacter+ F.Y.M. 20tha ${ }^{-1} ; T_{10}-P S B+$ Azospirillum+Azotobacter+F.Y.M 20 tha $^{-1}$ + Vermicompost $5 \mathrm{t} \mathrm{ha}^{-1}$. The treatment was laid out in randomized block design with three replicates each having five seedlings. Inoculation of these organics was done around root zone of each seedling and plants were irrigated quickly. Cultural operation was done as and when required. Soil samples were collected after 30 , 60, 120 and 180 days of soil incubation (DSI)of organics for analysis of rhizosphere and bulk soil properties, root and alkaloid yield following standard procedures (Khajuria et al., 2004; Pareek and Yadav, 2011). In second set of experiment, the plants were grown randomly in field conditions in soils of subtropical and intermediate zones for studying their performance in terms of dry biomass, dry root yield and alkaloid content.

Collection and preparation of soil sample : Samples were collected from rhizosphere and bulk soils at $0-15 \mathrm{~cm}$ depth around root zone in respective treatment. Representative soil samples of about $1 / 2 \mathrm{~kg}$ were prepared and placed in polythene bags. $A$ portion of each soil sample was air dried, ground in a wooden pestle with mortar and passed through a $2 \mathrm{~mm}$ stainless steel sieve for determining various physico-chemical soil properties as per the standard procedures.

Collection and preparation of plant sample : Plant samples were collected and data was recorded on four randomly selected plants from three replicates, weighed as a whole as dry biomass (g plant $\mathrm{t}^{-1}$ ), dry root yield (g plant ${ }^{-1}$ ) and total alkaloids for each respective parameter at vegetative and at seed maturity stage in first set of experiment whereas the data was recorded on six randomly selected plants in $2^{\text {nd }}$ set of experiment. The alkaloid content was estimated at vegetative phase and crop harvest through HPLC technique using standard markers.

Estimation of alkaloid: Withanolides were estimated following HPLC technique. One gram of finely powdered material was estimated three times with $3.0 \mathrm{ml}$ of methanol by sonication for 10 min. After centrifugation ( $5 \mathrm{~min}$ at $3000 \mathrm{rev} \mathrm{min}^{-1}$ ), the extracts were combined in $10 \mathrm{ml}$ in a volumetric flask and adjusted to final volume with methanol. The samples were diluted 3:2 ratio of methanol : water. All samples were passed through a $0.45 \mathrm{~mm}$ Nylaflo membrane filter from Gelman (Ann Arbor, M I, USA). All sample was injected in triplicate. Each standard compound was calibrated and detector response was linear. HPLC analysis was performed on a Shimadzu class-VP.V-6.14.HPLC system equipped with a photodiode array detector (off line). For all separations, a Synergi MAX-RP 18 E Column 4.6mm x 100 mm chromalith size $-5 \mu \mathrm{m}$ was used. The separation temperature was kept constant at $30^{\circ} \mathrm{C}$ flow rate and sample volume was set to $0.5 \mathrm{ml} \mathrm{min}^{-1}$ and $10 \mu \mathrm{l}$, respectively. All separations were monitored at $237 \mathrm{~nm}$. The withanolides were identified as withanolide-A, withanone and withaferin-A. Peaks were assigned by spiking the samples with standard markers available for these withanolides and comparison of UV-spectra and retention times. 


\section{Results and Discussion}

The perusal of data reveals that $\mathrm{pH}$ and $\mathrm{EC}$ of soil decreased with application of organic source alone or in combination with different treatments both in rhizosphere and bulk soil, no doubt the change in $\mathrm{pH}$ was prominent in rhizosphere soil than bulk soil. The application of organic source reduced $\mathrm{pH}$ to the level of 6.85 and 6.87 in $T_{10}$ treatment at 180 days of soil incubation in contrast to the control which exhibited 7.07 and 7.13, respectively, in rhizosphere and bulk soil. Among various organic sources applied, different combinations of organics depicted greater effect rather than sole application of organic sources. The change in $\mathrm{pH}$ of soil was more pronounced at 180 days of soil incubation, followed by 120,60 and 30 days of soil incubation (Table 1). The data pertaining to the effect of different organic sources on soil reaction $(\mathrm{pH})$ revealed that the decrease in soil $\mathrm{pH}$ ranged from 7.09 to 6.85 and 7.14 to 6.87 in rhizosphere and bulk soil, irrespective of treatment and days of soil incubation. There was slight decrease in $\mathrm{pH}$ with organic application and that may be ascribed to the release of organic acids (Kumar et al., 2008). This may be due to acid equivalent which might have a direct effect on increase in soil acidity as reported by Pathak et al. (2005).

The electrical conductivity $\left(\mathrm{dSm}^{-1}\right)$ of soil increased with application of organics alone and in combination with different treatment both in rhizosphere and bulk soil. The change in electrical conductivity was dominant in rhizophere soil than in bulk soil. The application of organics increased E.C. to the level of 0.60 and $0.55 \mathrm{E} . \mathrm{C} \mathrm{dSm}{ }^{-1}$ and was contrary to the control that exhibited 0.41 and $0.37 \mathrm{dSm}^{-1}$ respectively in the rhizosphere and bulk soil in $T_{10}$ at 180 days of soil incubation. Among organic sources, the combined application of organics increased the soil electrical conductivity remarkably rather than sole application of organic sources. The increased electrical conductivity of soil was more pronounced at 180 days of soil incubation followed by 120,60 and 30 days of soil incubation as depicted in Table 2. The water soluble salts expressed as electrical conductivity increased from 0.43 to 0.60 and 0.40 to $0.55 \mathrm{dSm}^{-1}$ both in rhizosphere and bulk soils, irrespective of treatment and days of soil incubation (Table 2) with the application of organics which might be due to decomposition of organic matter in soil as (Atiyeh et al., 2001). Application of bio-fertilizer may have resulted in increase of microbial population in rhizosphere of organic matter, leading to increase in electrical conductivity as reported by Babu et al. (2007). The data indicated that change in $\mathrm{pH}$ and $\mathrm{EC}$ due to different treatments was significant when compared with control, although many of the treatments were significant when compared to each other.

The organic carbon, available nitrogen, available phosphorous and available potassium of soil increased with application of organic source alone and in combination with different treatments both in rhizosphere and bulk soil. The concentration of organic carbon was dominant in rhizosphere soil than in bulk soil. Among organic sources applied different combinations of organics showed pronounced effect as compared to sole application alone in increasing the organic carbon, available nitrogen, available phosphorous and available potassium content. The increase in organic carbon, available nitrogen, available phosphorous and available potassium due to different organic treatments was significant when compared with control and among other treatments in most of treatments.

The soil organic carbon increased with application of organics. In case of different organics, organic carbon increased to

Table 1 : Effect of organics on $\mathrm{pH}$ in rhizosphere and bulk soil of Withania somnifera

\begin{tabular}{|c|c|c|c|c|c|c|c|c|}
\hline \multirow[b]{3}{*}{ Treatments } & \multicolumn{4}{|c|}{ Rhizosphere soil } & \multicolumn{4}{|c|}{ Bulk soil } \\
\hline & $30 \mathrm{DSI}^{*}$ & $60 \mathrm{DSI}^{*}$ & $120 \mathrm{DSI}^{*}$ & 180 DSI$^{*}$ & $30 \mathrm{DSI}^{*}$ & $60 \mathrm{DSI}^{*}$ & 120DSI* & $180 \mathrm{DSI}^{*}$ \\
\hline & Mean** & Mean** & Mean** & $\operatorname{Mean}^{* *}$ & Mean** & Mean** & $\operatorname{Mean}^{* *}$ & $\operatorname{Mean}^{* *}$ \\
\hline $\mathrm{T}_{0}$ & 7.09 & 7.08 & 7.07 & 7.07 & 7.14 & 7.14 & 7.13 & 7.13 \\
\hline $\mathrm{T}_{1}$ & 7.07 & 7.06 & 7.04 & 7.03 & 7.09 & 7.08 & 7.05 & 7.04 \\
\hline $\mathrm{T}_{2}$ & 7.06 & 7.04 & 7.01 & 6.98 & 7.09 & 7.05 & 7.03 & 6.99 \\
\hline $\mathrm{T}_{3}$ & 7.07 & 7.05 & 7.04 & 7.01 & 7.08 & 7.06 & 7.05 & 7.02 \\
\hline $\mathrm{T}_{4}$ & 7.03 & 7.01 & 6.98 & 6.97 & 7.05 & 7.03 & 7.00 & 6.98 \\
\hline $\mathrm{T}_{5}$ & 6.97 & 6.97 & 6.95 & 6.88 & 7.02 & 6.99 & 6.96 & 6.96 \\
\hline $\mathrm{T}_{6}$ & 6.94 & 6.94 & 6.90 & 6.87 & 6.99 & 6.96 & 6.93 & 6.89 \\
\hline $\mathrm{T}_{7}$ & 6.96 & 6.93 & 6.89 & 6.86 & 6.97 & 6.95 & 6.92 & 6.88 \\
\hline $\mathrm{T}_{8}$ & 7.04 & 7.03 & 6.98 & 6.95 & 7.06 & 7.04 & 7.01 & 6.99 \\
\hline $\mathrm{T}_{9}$ & 6.98 & 6.94 & 6.93 & 6.89 & 7.00 & 6.98 & 6.94 & 6.93 \\
\hline $\mathrm{T}_{10}$ & 6.95 & 6.93 & 6.88 & 6.85 & 6.96 & 6.95 & 6.91 & 6.87 \\
\hline Mean*** & 7.01 & 6.99 & 6.97 & 6.94 & 7.04 & 7.02 & 6.99 & 6.97 \\
\hline C.D (0.05) & 0.052 & 0.046 & 0.034 & 0.029 & 0.056 & 0.048 & 0.038 & 0.032 \\
\hline
\end{tabular}

*Days after soil incubation; **Mean indicates average value of three replicates; ${ }^{* *}$ Mean indicates average value of treatments (S) 
the level of 0.71 and 0.69 in $T_{10}$ in contrast to control which exhibited 0.53 and 0.52 in rhizosphere and bulk soil at 120 days of soil incubation. The results go in line with other workers (Mekki et al., 2017) who also reported similar kinds of results. The increase in organic carbon was more pronounced 120 days of soil incubation as followed by 60 and 30 days of soil incubation (Table 3). The value indicated a slight decline 180 of after soil incubation but was remarkably higher 30 days of soil incubation.

Application of organics increased the organic carbon content from 0.54 to 0.71 and 0.53 to 0.69 both in rhizosphere and bulk, irrespective of treatment and days of soil incubation (Table
3) as also reported by Pareek and Yadav (2011). With the application of organics, there was a build up of organic carbon in soil which could be due to enhanced root growth, resulting more organic residues in soil, which after decomposition might have increased the soil organic carbon content. These findings are in conformity with the findings of Kumpawat and Jat, (2005); Balyan et al. (2006) and Pareek and Yadav (2011).

Every enhanced application of organic source increased available nitrogen content in soil. Available nitrogen in soil increased to the level of $145.1 \mathrm{mg} \mathrm{kg}^{-1}$ and $143.4 \mathrm{mg} \mathrm{kg}^{-1}$ in $\mathrm{T}_{10}$ as compared to control (123.6 $\mathrm{mg} \mathrm{kg}^{-1}$ and $123.2 \mathrm{mg} \mathrm{kg}^{-1}$ ) in the

Table 2 : Effect of organics on electrical conductivity $\left(\mathrm{dS} \mathrm{m}^{-1}\right)$ in rhizosphere and bulk soil of Withania somnifera

\begin{tabular}{|c|c|c|c|c|c|c|c|c|}
\hline \multirow[b]{3}{*}{ Treatments } & \multicolumn{4}{|c|}{ Rhizosphere soil } & \multicolumn{4}{|c|}{ Bulk soil } \\
\hline & $30 \mathrm{DSl}^{*}$ & $60 \mathrm{DSI}^{*}$ & $120 \mathrm{DSI}^{*}$ & $180 \mathrm{DSI}^{*}$ & $30 \mathrm{DSI}^{*}$ & $60 \mathrm{DSI}^{*}$ & $120 \mathrm{DSI}^{*}$ & $180 \mathrm{DSI}^{*}$ \\
\hline & Mean** & Mean $^{\star *}$ & Mean $^{\star *}$ & Mean $^{\star *}$ & Mean** & Mean* & Mean $^{\star *}$ & Mean $^{\star *}$ \\
\hline $\mathrm{T}_{0}$ & 0.43 & 0.43 & 0.42 & 0.41 & 0.40 & 0.38 & 0.38 & 0.37 \\
\hline $\mathrm{T}_{1}$ & 0.44 & 0.45 & 0.46 & 0.48 & 0.41 & 0.43 & 0.45 & 0.47 \\
\hline $\mathrm{T}_{2}$ & 0.44 & 0.46 & 0.47 & 0.48 & 0.41 & 0.44 & 0.44 & 0.44 \\
\hline $\mathrm{T}_{3}$ & 0.44 & 0.44 & 0.44 & 0.45 & 0.41 & 0.43 & 0.43 & 0.44 \\
\hline $\mathrm{T}_{4}$ & 0.46 & 0.47 & 0.49 & 0.51 & 0.45 & 0.46 & 0.48 & 0.49 \\
\hline $\mathrm{T}_{5}$ & 0.47 & 0.49 & 0.51 & 0.52 & 0.46 & 0.50 & 0.50 & 0.51 \\
\hline $\mathrm{T}_{6}$ & 0.44 & 0.47 & 0.49 & 0.51 & 0.43 & 0.46 & 0.48 & 0.50 \\
\hline $\mathrm{T}_{7}$ & 0.44 & 0.45 & 0.48 & 0.48 & 0.42 & 0.44 & 0.45 & 0.47 \\
\hline $\mathrm{T}_{8}$ & 0.47 & 0.47 & 0.50 & 0.52 & 0.46 & 0.45 & 0.49 & 0.50 \\
\hline $\mathrm{T}_{9}$ & 0.48 & 0.48 & 0.50 & 0.53 & 0.43 & 0.46 & 0.49 & 0.49 \\
\hline $\mathrm{T}_{10}$ & 0.50 & 0.54 & 0.56 & 0.60 & 0.47 & 0.52 & 0.53 & 0.55 \\
\hline Mean*** & 0.45 & 0.46 & 0.48 & 0.49 & 0.43 & 0.45 & 0.46 & 0.47 \\
\hline C.D(0.05) & 0.041 & 0.042 & 0.044 & 0.046 & 0.041 & 0.043 & 0.044 & 0.045 \\
\hline
\end{tabular}

${ }^{*}$ Days after soil incubation; ${ }^{* *}$ Mean indicates average value of three replicates; ${ }^{* *}$ Mean indicates average value of treatments (S)

Table 3 : Effect of organics on organic carbon (\%) in rhizosphere and bulk soil of Withania somnifera

\begin{tabular}{|c|c|c|c|c|c|c|c|c|}
\hline \multirow[b]{3}{*}{ Treatments } & \multicolumn{4}{|c|}{ Rhizosphere soil } & \multicolumn{4}{|c|}{ Bulk soil } \\
\hline & $30 \mathrm{DSI}^{*}$ & $60 \mathrm{DSI}^{*}$ & 120DSI* & 180 DSI* & 30DSI* & $60 \mathrm{DSI}^{*}$ & 120DSI* & $180 \mathrm{DSI}^{*}$ \\
\hline & Mean** & Mean** & Mean** & Mean** & Mean** & Mean** & $\operatorname{Mean}^{* *}$ & $\operatorname{Mean}^{\star *}$ \\
\hline $\mathrm{T}_{1}$ & 0.54 & 0.54 & 0.53 & 0.53 & 0.53 & 0.52 & 0.52 & 0.51 \\
\hline $\mathrm{T}_{2}$ & 0.55 & 0.57 & 0.60 & 0.57 & 0.54 & 0.56 & 0.59 & 0.56 \\
\hline $\mathrm{T}_{3}$ & 0.56 & 0.60 & 0.62 & 0.58 & 0.55 & 0.57 & 0.58 & 0.57 \\
\hline $\mathrm{T}_{4}$ & 0.56 & 0.59 & 0.62 & 0.57 & 0.55 & 0.58 & 0.59 & 0.55 \\
\hline $\mathrm{T}_{5}$ & 0.60 & 0.64 & 0.65 & 0.61 & 0.59 & 0.62 & 0.64 & 0.60 \\
\hline $\mathrm{T}_{6}$ & 0.61 & 0.65 & 0.66 & 0.64 & 0.59 & 0.64 & 0.65 & 0.62 \\
\hline $\mathrm{T}_{7}$ & 0.63 & 0.66 & 0.69 & 0.64 & 0.60 & 0.64 & 0.66 & 0.62 \\
\hline $\mathrm{T}_{8}$ & 0.64 & 0.68 & 0.70 & 0.67 & 0.62 & 0.66 & 0.68 & 0.65 \\
\hline $\mathrm{T}_{9}$ & 0.59 & 0.62 & 0.64 & 0.59 & 0.57 & 0.60 & 0.63 & 0.58 \\
\hline $\mathrm{T}_{10}$ & 0.62 & 0.65 & 0.68 & 0.64 & 0.61 & 0.64 & 0.67 & 0.63 \\
\hline $\mathrm{T}_{11}$ & 0.66 & 0.71 & 0.71 & 0.68 & 0.63 & 0.67 & 0.69 & 0.67 \\
\hline Mean*** & 0.59 & 0.62 & 0.64 & 0.61 & 0.58 & 0.60 & 0.62 & 0.59 \\
\hline C.D $(0.05)$ & 0.017 & 0.017 & 0.020 & 0.017 & 0.016 & 0.015 & 0.018 & 0.016 \\
\hline
\end{tabular}

*Days after soil incubation; **Mean indicates average value of three replicates; *** Mean indicates average value of treatments (S) 
rhizosphere and bulk soil at 120 days of soil incubation. The available nitrogen content was maximum at 120 days of soil incubation, followed by 60 and 30 days of soil incubation (Table 4). The value showed a slight decline at 180 days of soil incubation but was higher than those at 30 days of soil incubation.

Available soil nitrogen increased from 125.6 to $145.1 \mathrm{mg}$ $\mathrm{kg}^{-1}$ and 125.0 to $143.4 \mathrm{mg} \mathrm{kg}^{-1}$ both in rhizosphere and bulk soil, irrespective of treatment and days of soil incubation (Table 4). Similar results were also reported by Tolanur and Badanur, (2003) and Balyan et al. (2006). The increase in available nitrogen in soil may be due to application of combined organics which could be attributed to multiplication of microbes in and conversion of organically bound nitrogen to inorganic form (Sharma et al., 2009; Tolanur and Badanur, 2003; and Balyan et al., 2006). Besides fixation by heterotrophic bacteria in soil is markedly stimulated by favourable soil conditions under treatment receiving organic manure that might have helped in better nodulation and root growth leading to build up of available soil nitrogen content after transplanting. Bajpai et al. (2006); Subashchand and Ram (2007). A significant increase in soil available nitrogen by organic manure amendment has been reported earlier (Bajpai et al., 2006; Subaschand and Ram, 2007). The nitrogen content increased from 30 to 120 days of soil incubation but slightly

Table 4 : Effect of organics on available nitrogen $\left(\mathrm{mg} \mathrm{kg}^{-1}\right)$ in rhizosphere and bulk soil of Withania somnifera

\begin{tabular}{|c|c|c|c|c|c|c|c|c|}
\hline \multirow[b]{3}{*}{ Treatments } & \multicolumn{4}{|c|}{ Rhizosphere soil } & \multicolumn{4}{|c|}{ Bulk soil } \\
\hline & $30 \mathrm{DSI}^{*}$ & $60 \mathrm{DSI}^{*}$ & $120 \mathrm{DSI}^{*}$ & $180 \mathrm{DSI}^{*}$ & $30 \mathrm{DSI}^{*}$ & $60 \mathrm{DSI}{ }^{*}$ & $120 \mathrm{DSI}^{*}$ & $180 \mathrm{DSI}^{*}$ \\
\hline & Mean** & Mean** & Mean** & Mean** & Mean** & Mean** & Mean** & Mean** \\
\hline $\mathrm{T}_{1}$ & 125.6 & 124.8 & 123.6 & 121.2 & 125.0 & 124.6 & 123.2 & 120.3 \\
\hline $\mathrm{T}_{2}$ & 126.2 & 132.9 & 136.7 & 133.3 & 125.7 & 131.9 & 136.1 & 132.7 \\
\hline $\mathrm{T}_{3}$ & 126.2 & 134.0 & 136.6 & 134.01 & 124.0 & 133.1 & 135.5 & 133.9 \\
\hline $\mathrm{T}_{4}$ & 130.2 & 133.7 & 137.8 & 133.1 & 129.9 & 133.1 & 137.1 & 132.8 \\
\hline $\mathrm{T}_{5}$ & 129.3 & 135.3 & 138.7 & 134.8 & 128.0 & 134.8 & 138.0 & 134.0 \\
\hline $\mathrm{T}_{6}$ & 131.7 & 136.8 & 139.8 & 133.6 & 129.1 & 136.2 & 139.2 & 133.0 \\
\hline $\mathrm{T}_{7}$ & 133.4 & 137.5 & 140.7 & 135.4 & 132.5 & 136.8 & 140.3 & 134.9 \\
\hline $\mathrm{T}_{8}$ & 134.0 & 137.8 & 141.9 & 137.3 & 132.7 & 137.4 & 141.1 & 136.0 \\
\hline $\mathrm{T}_{9}$ & 129.1 & 133.8 & 137.1 & 132.0 & 127.7 & 133.4 & 136.1 & 131.8 \\
\hline $\mathrm{T}_{10}$ & 132.5 & 137.0 & 140.0 & 135.5 & 129.2 & 136.7 & 139.8 & 134.7 \\
\hline $\mathrm{T}_{11}$ & 135.5 & 139.5 & 145.1 & 138.5 & 134.1 & 138.9 & 143.4 & 137.8 \\
\hline Mean*** & 130.3 & 134.8 & 137.9 & 133.5 & 128.9 & 134.3 & 137.3 & 132.9 \\
\hline C.D $(0.05)$ & 1.387 & 1.231 & 1.343 & 1.184 & 1.418 & 1.272 & 1.376 & 1.272 \\
\hline
\end{tabular}

*Days after soil incubation; ${ }^{* *}$ Mean indicates average value of three replicates; ${ }^{* * *}$ Mean indicates average value of treatments (S)

Table 5 : Effect of organics on available phosphorus $\left(\mathrm{mg} \mathrm{kg}^{-1}\right)$ in rhizosphere and bulk soil of Withania somnifera

\begin{tabular}{|c|c|c|c|c|c|c|c|c|}
\hline \multirow[b]{3}{*}{ Treatments } & \multicolumn{4}{|c|}{ Rhizosphere soil } & \multicolumn{4}{|c|}{ Bulk soil } \\
\hline & $30 \mathrm{DSI}^{*}$ & $60 \mathrm{DSI}^{*}$ & $120 \mathrm{DS} I^{*}$ & 180 DSI$^{*}$ & $30 \mathrm{DSI}^{*}$ & $60 \mathrm{DSI}^{*}$ & 120DSI* & $180 \mathrm{DSI}^{*}$ \\
\hline & Mean** & Mean $^{* *}$ & $\operatorname{Mean}^{* *}$ & Mean $^{* *}$ & Mean** & Mean $^{* *}$ & $\operatorname{Mean}^{\star *}$ & $\operatorname{Mean}^{\star *}$ \\
\hline $\mathrm{T}_{0}$ & 6.32 & 6.30 & 6.26 & 6.26 & 6.31 & 6.28 & 6.22 & 6.21 \\
\hline $\mathrm{T}_{1}$ & 7.39 & 8.95 & 9.10 & 7.35 & 7.20 & 8.5 & 9.01 & 8.19 \\
\hline $\mathrm{T}_{2}$ & 7.14 & 8.04 & 8.14 & 7.37 & 7.07 & 7.95 & 8.11 & 7.29 \\
\hline $\mathrm{T}_{3}$ & 7.35 & 8.25 & 8.54 & 7.97 & 7.11 & 8.05 & 8.21 & 7.86 \\
\hline $\mathrm{T}_{4}$ & 7.27 & 8.56 & 8.93 & 7.70 & 7.22 & 8.30 & 8.86 & 7.65 \\
\hline $\mathrm{T}_{5}$ & 7.95 & 9.27 & 9.62 & 8.21 & 7.16 & 9.20 & 9.23 & 8.19 \\
\hline $\mathrm{T}_{6}$ & 8.06 & 9.4 & 9.49 & 8.66 & 7.78 & 9.35 & 9.22 & 8.34 \\
\hline $\mathrm{T}_{7}$ & 8.13 & 9.67 & 10.13 & 9.46 & 7.89 & 9.66 & 10.04 & 9.02 \\
\hline $\mathrm{T}_{8}$ & 7.20 & 7.86 & 8.98 & 8.71 & 7.01 & 7.97 & 8.11 & 7.61 \\
\hline $\mathrm{T}_{9}$ & 7.95 & 9.77 & 9.94 & 9.09 & 8.04 & 9.53 & 9.45 & 8.63 \\
\hline $\mathrm{T}_{10}$ & 9.29 & 11.25 & 12.05 & 10.59 & 8.23 & 9.90 & 11.12 & 9.86 \\
\hline Mean*** & 7.64 & 8.84 & 9.24 & 8.30 & 7.36 & 8.60 & 8.87 & 8.06 \\
\hline C.D $(0.05)$ & 0.471 & 0.412 & 0.390 & 0.374 & 0.319 & 0.503 & 0.411 & 0.415 \\
\hline
\end{tabular}

${ }^{*}$ Days after soil incubation; ${ }^{* \star}$ Mean indicates average value of three replicates; ${ }^{* \star}$ Mean indicates average value of treatments (S) 
decreased at 180 days of soil incubation. This might be due to the increased absorption of nitrogen by plants during their growth (Ramakrishnaiah and Vijaya, 2013).

It was observed that phosphorus content in soil increased with application of organic source either alone or in combination with different organics both in rhizosphere and bulk soil, no doubt that the available phosphorus was more in rhizosphere soil higher than in bulk soil. Every enhanced application of organic source increased the available phosphorus in soil. In case of different organic sources, phosphorous level increased to the level of 12.05 and $11.12 \mathrm{mg} \mathrm{kg}^{-1}$ at 120 days of soil incubation in $\mathrm{T}_{10}$ treatment on the contrary to the control which exhibited 6.26 and $6.22 \mathrm{mg} \mathrm{kg}^{-1}$, respectively, in both rhizosphere and bulk soil 120 days of soil incubation. The available phosphorus content (mg $\mathrm{kg}^{1}$ ) was maximum at 120 followed by 60 and 30 days of soil incubation. The available phosphorus content slightly decreased at 180 days of soil incubation but was remarkably higher than 30 days of soil incubation (Table 5)

Incorporation of different organics increased available soil phosphorus from 6.32 to $12.05 \mathrm{mg} \mathrm{kg}^{-1}$ and 6.31 to $11.12 \mathrm{mg}$ $\mathrm{kg}^{-1}$ both in rhizosphere and bulk soil irrespective of treatment and days of soil incubation (Table 5). However, different combinations

Table 6 : Effect of organics on available potassium $\left(\mathrm{mg} \mathrm{kg}^{-1}\right)$ in rhizosphere and bulk soil of Withania somnifera

\begin{tabular}{|c|c|c|c|c|c|c|c|c|}
\hline \multirow[b]{3}{*}{ Treatments } & \multicolumn{4}{|c|}{ Rhizosphere soil } & \multicolumn{4}{|c|}{ Bulk soil } \\
\hline & $30 \mathrm{DSI}^{*}$ & $60 \mathrm{DSI}^{*}$ & $120 \mathrm{DSI}^{*}$ & $180 \mathrm{DSI}^{*}$ & $30 \mathrm{DSI}^{*}$ & $60 \mathrm{DSI}^{*}$ & $120 \mathrm{DSI}^{*}$ & $180 \mathrm{DS} I^{*}$ \\
\hline & Mean & Mean & Mean & Mean & Mean & Mean & Mean & Mean \\
\hline $\mathrm{T}_{1}$ & 95.6 & 95.3 & 94.1 & 93.6 & 94.7 & 93.1 & 92.2 & 92.0 \\
\hline $\mathrm{T}_{2}$ & 96.9 & 105.6 & 109.1 & 102.5 & 95.3 & 105.2 & 108.2 & 100.9 \\
\hline $\mathrm{T}_{3}$ & 95.7 & 105.5 & 108.5 & 102.7 & 95.2 & 105.1 & 107.4 & 102.1 \\
\hline $\mathrm{T}_{4}$ & 98.8 & 106.3 & 110.5 & 103.3 & 95.1 & 104.6 & 109.3 & 103.0 \\
\hline $\mathrm{T}_{5}$ & 97.8 & 106.4 & 109.8 & 103.2 & 97.2 & 105.4 & 109.3 & 101.9 \\
\hline $\mathrm{T}_{6}$ & 98.7 & 108.2 & 110.5 & 103.2 & 98.2 & 107.5 & 110.2 & 102.5 \\
\hline $\mathrm{T}_{7}$ & 100.1 & 110.2 & 112.3 & 105.5 & 99.4 & 109.8 & 111.6 & 104.1 \\
\hline $\mathrm{T}_{8}$ & 100.4 & 111.2 & 114.5 & 107.5 & 99.7 & 110.6 & 113.5 & 104.0 \\
\hline $\mathrm{T}_{9}$ & 99.1 & 105.8 & 109.6 & 103.4 & 97.0 & 104.7 & 109.2 & 102.6 \\
\hline $\mathrm{T}_{10}$ & 99.8 & 108.7 & 114.1 & 106.2 & 99.2 & 108.1 & 110.3 & 103.9 \\
\hline $\mathrm{T}_{11}$ & 102.0 & 112.5 & 116.6 & 109.8 & 101.7 & 112.0 & 115.2 & 108.2 \\
\hline Mean*** & 98.6 & 106.8 & 109.9 & 103.7 & 97.5 & 106.0 & 108.8 & 102.2 \\
\hline C.D $(0.05)$ & 1.168 & 1.355 & 1.460 & 1.355 & 1.209 & 1.418 & 1.422 & 1.501 \\
\hline
\end{tabular}

*Days after soil incubation; **Mean indicates average value of three replicates; ${ }^{* * \star}$ Mean indicates average value of treatments (S)

Table 7 : Effect of organics on dry biomass, root yield and alkaloid content (\%) of Withania somnifera

\begin{tabular}{|c|c|c|c|c|c|c|}
\hline \multirow[b]{2}{*}{ Treatments } & \multicolumn{2}{|c|}{ Dry biomass (g plant ${ }^{-1}$ ) (aboveground) } & \multicolumn{2}{|c|}{ Dry root yield (g plant ${ }^{-1}$ ) } & \multicolumn{2}{|c|}{ Alkaloid content(\%) } \\
\hline & $\begin{array}{l}\text { Vegetative } \\
\text { Mean }{ }^{\star *}\end{array}$ & $\begin{array}{l}\text { Maturity } \\
\text { Mean** }^{* *}\end{array}$ & $\begin{array}{l}\text { Vegetative } \\
\text { Mean }{ }^{\star *}\end{array}$ & $\begin{array}{l}\text { Seed Maturity } \\
\text { Mean** }^{* *}\end{array}$ & $\begin{array}{l}\text { Vegetative } \\
\text { Mean** }^{* *}\end{array}$ & $\begin{array}{l}\text { Seed Maturity } \\
\text { Mean }{ }^{* *}\end{array}$ \\
\hline $\mathrm{T}_{0}$ & 22.80 & 24.20 & 3.26 & 5.48 & 0.0794 & 0.0915 \\
\hline $\mathrm{T}_{1}$ & 26.82 & 28.90 & 5.02 & 7.02 & 0.0875 & 0.0989 \\
\hline $\mathrm{T}_{2}$ & 24.42 & 26.57 & 5.10 & 7.12 & 0.0854 & 0.0912 \\
\hline $\mathrm{T}_{3}$ & 24.24 & 26.43 & 4.82 & 6.92 & 0.1031 & 0.1188 \\
\hline $\mathrm{T}_{4}$ & 27.12 & 29.36 & 5.13 & 7.23 & 0.0971 & 0.0990 \\
\hline $\mathrm{T}_{5}^{4}$ & 24.02 & 25.25 & 4.89 & 6.98 & 0.1045 & 0.1095 \\
\hline $\mathrm{T}_{6}$ & 27.32 & 29.48 & 4.12 & 6.29 & 0.1013 & 0.1038 \\
\hline $\mathrm{T}_{7}$ & 25.12 & 26.29 & 4.08 & 6.12 & 0.1024 & 0.1048 \\
\hline $\mathrm{T}_{8}$ & 24.24 & 25.66 & 4.02 & 6.06 & 0.0862 & 0.0924 \\
\hline $\mathrm{T}_{9}$ & 24.12 & 25.43 & 5.21 & 7.28 & 0.0965 & 0.0980 \\
\hline $\mathrm{T}_{10}$ & 27.58 & 29.62 & 6.28 & 8.32 & 0.1087 & 0.1218 \\
\hline Mean*** & 25.25 & 27.01 & 4.72 & 6.80 & 0.0956 & 0.1775 \\
\hline C.D $(0.05)$ & NS & 3.652 & NS & 2.821 & NS & 0.0792 \\
\hline
\end{tabular}

${ }^{* *}$ Mean indicates average value of three replicates ${ }^{* * *}$ Mean indicates average value of treatments (S) 
of organics recorded significantly higher available phosphorous than sole application as also reported by Vasant et al., (2012). A significant increase in available phosphorous status of the soil might be due to release of soluble inorganic phosphates into soil through decomposition of phosphate rich organic compounds and secretion of organic acids which may form chelates with the Al resulting effective solubilization of phosphates (Shinde and Patil, 1985). The available phosphorus slightly decreased at 180 days of soil incubation, which might be due to greater uptake by crops. The result of present investigation corroborates with those of Das etal. (2008)

The perusal of data revealed that available potassium in soil increased with application of organic sources alone and also in combination with different treatments both in rhizosphere and bulk soil, no doubt the available potassium was higher in rhizosphere soil than that of bulk soil. Every enhanced application of organic source significantly increased the available potassium in soil. In case of different organic source application, available potassium increased to the level of 116.6 and $115.2 \mathrm{mg} \mathrm{kg}^{-1} 120$ days of soil incubation in $T_{10}$ as compared to the control. The available potassium content was maximum at 120 days of soil incubation, followed by 60 and 30 days of soil incubation. At 180 days of soil incubation potassium content decreased slightly but was higher than 30 days of soil incubation (Table 6).

Different combinations of organics increased available soil potassium from 95.6 to $116.6 \mathrm{mg} \mathrm{kg}^{-1}$ and 94.7 to $115.2 \mathrm{mg} \mathrm{kg}^{-1}$
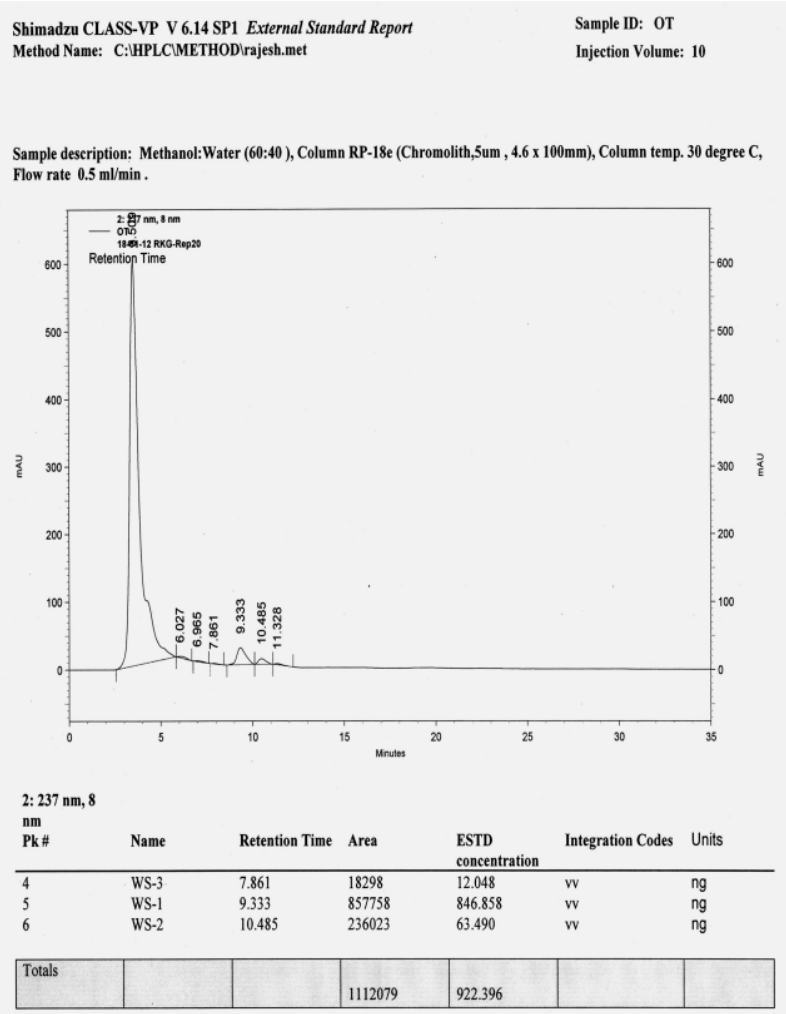

both in rhizosphere and bulk soil irrespective of treatment and days of soil incubation. Available $\mathrm{K}$ was also higher in combined application of organics because organic acids and inorganic acids produced during decomposition of organic manures help in releasing mineral bound insoluble potassium and also reduce potassium fixation (Vasant et al., 2012), The available potassium slightly decreased at 180 days of soil incubation due to higher uptake by crops (Das et al., 2008).

The seedlings grown with different organics showed increased plant biomass and root yield as compared to control. Among various organic sources, the combined application of $T_{10}$ yielded maximum dry plant biomass and dry root yield at vegetative stage and at seed maturity stage, respectively, as compared to control.

Similarly, alkaloid content showed $0.1088 \%$ increase at vegetative stage and $0.1218 \%$ increase at seed maturity stage in $\mathrm{T}_{10}$ treatment.

Higher yield may be due to application of organics which attributed to favourable effect in improving the physical condition of soil, beside supplying adequate nutrients which may have enhanced the absorption, translocation and assimilation of nutrients resulting in higher biomass.
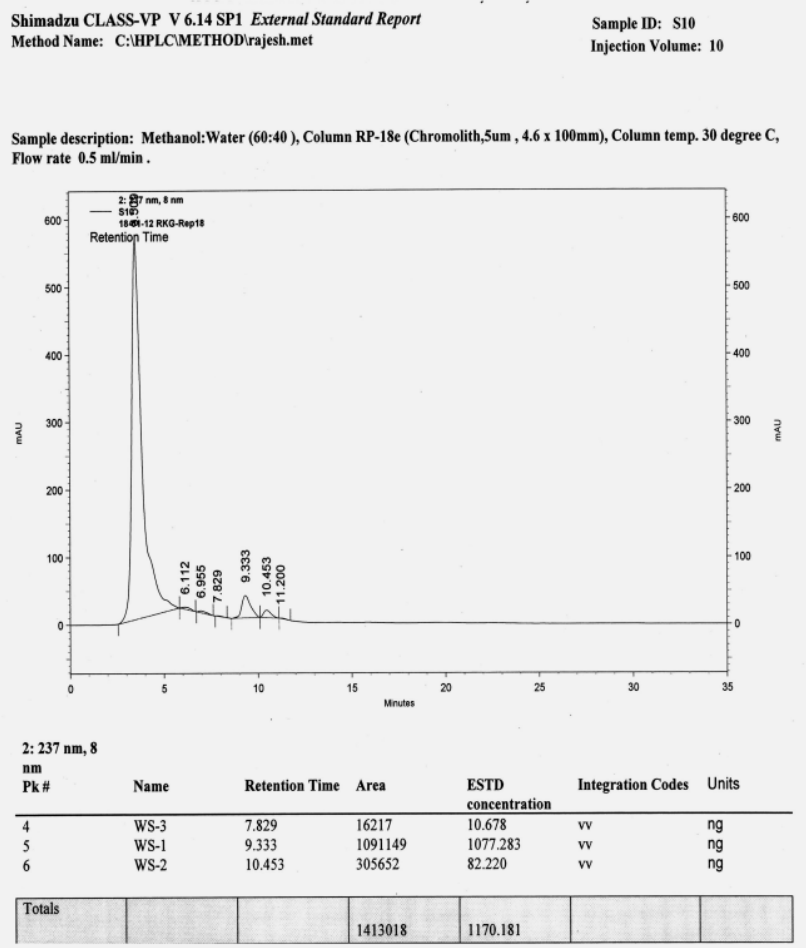

Fig. 1 : Alkaloid content (withanolide $\%$ ) at $T_{0}(1 a)$ and $T_{10}(1 b)$. 
Table 8: Dry biomass, root yield and alkaloid content (\%) of Withania somnifera in soils of subtropical and intermediate zones of Jammu district

\begin{tabular}{|c|c|c|c|c|}
\hline & \multicolumn{3}{|c|}{ Sub-tropical zone } & \multirow{2}{*}{$\begin{array}{l}\text { Intermediate zone } \\
\text { Rajouri }\end{array}$} \\
\hline & Jammu & Chatha & Kathua & \\
\hline Latitude & $32^{\circ} 44^{\prime} \mathrm{N}$ & $32^{\circ} 29^{\prime} \mathrm{N}$ & $32^{\circ} 36^{\prime} \mathrm{N}$ & $33^{\circ} 23^{\prime} \mathrm{N}$ \\
\hline Longitude & $14^{\circ} 55^{\prime} \mathrm{E}$ & $74^{\circ} 48^{\prime} \mathrm{E}$ & $75^{\circ} 36^{\prime} \mathrm{E}$ & $74^{\circ} 20^{\prime} \mathrm{E}$ \\
\hline Average temperature & $30.4^{\circ} \mathrm{C}$ & $29^{\circ} \mathrm{C}$ & $24^{\circ} \mathrm{C}$ & $20^{\circ} \mathrm{C}$ \\
\hline MSL & 400 m above msl & $360 \mathrm{~m}$ above $\mathrm{msl}$ & 317 m above msl & $1152 \mathrm{~m}$ above msl \\
\hline $\mathrm{pH}$ & 7.8 & 7.2 & 7.10 & 6.90 \\
\hline $\mathrm{EC}\left(\mathrm{dsm}^{-1}\right)$ & 0.48 & 0.45 & 0.42 & 0.46 \\
\hline $\mathrm{OC}(\%)$ & 0.58 & 0.57 & 0.56 & 0.58 \\
\hline \multicolumn{5}{|c|}{$\begin{array}{l}\text { Plant dry biomass* } \\
\text { (aboveground, } g \text { plant }^{-1} \text { ) }\end{array}$} \\
\hline Vegetative stage & 23.2 & 23.0 & 22.8 & 22.6 \\
\hline Seed maturity & 39.2 & 38.2 & 37.8 & 37.4 \\
\hline \multicolumn{5}{|l|}{ Dry root yield * $\left(\right.$ g plant $\left.^{-1}\right)$} \\
\hline Vegetative stage & 3.45 & 3.42 & 3.40 & 3.38 \\
\hline $\begin{array}{l}\text { Seed maturity stage } \\
\text { Alkaloid content }(\%)^{*}\end{array}$ & 4.95 & 4.80 & 4.70 & 4.68 \\
\hline Vegetative stage & 0.0962 & 0.0956 & 0.0872 & 0.0698 \\
\hline Seed maturity stage & 0.1827 & 0.1775 & 0.0899 & 0.0818 \\
\hline
\end{tabular}

${ }^{*}$ Indicates mean value

Accumulation of alkaloid content (withanolides) in roots significantly enhanced on application of vermicompost, farm yard manure and biofertilizer inoculation due to slow release and long duration of crop. High values at maturity stage of crop may be due to oxidation of starch and its conversion into alkaloids and production of more precursory compounds which accumulated in thicker plants and heavy roots Kumar et al. (2009). Further, bacterial inoculation through various organics might have increased $\mathrm{Ca}$ and $\mathrm{Mg}$ in plants. This increase could be due to production of organic acids by bacteria and plants in the rhizosphere which decreased soil $\mathrm{pH}$ and stimulated the availability of various nutrients, which in turn improved plant and root biomass and alkaloid content.

The dry plant biomass (23. $2 \mathrm{~g} \mathrm{plant}^{-1}$ and $\left.39.2 \mathrm{~g} \mathrm{plant}^{-1}\right)$ was higher in Jammu soil, followed by Chatha ( 23.0 and $38.2 \mathrm{~g}$ plant $^{-1}$ ) and Kathua (22.8 g plant $^{-1}$ and $37.8 \mathrm{~g} \mathrm{plant}^{-1}$ ) soil in sub tropical zone and least was recorded at Rajouri (22.6 g plant ${ }^{-1}$ and $\left.37.4 \mathrm{~g} \mathrm{plant}^{-1}\right)$ in intermediate zone at vegetative and seed maturity stages, respectively. The dry root yield followed same pattern in Jammu ( $3.45 \mathrm{~g} \mathrm{plant}^{-1}$ and $\left.4.95 \mathrm{~g} \mathrm{plant}^{-1}\right)$ followed by Chatha (3.42 g plant $^{-1}$ and 4.80 and $\mathrm{g} \mathrm{plant}^{-1}$ ) and Kathua $(3.40 \mathrm{~g}$ plant $^{-1}$ and $\left.4.70 \mathrm{~g} \mathrm{plant}^{1}\right)$ soils in subtropical zone and least was observed in Rajouri (3.38 $\mathrm{g}$ plant ${ }^{-1}$ and $4.68 \mathrm{~g} \mathrm{plant}^{-1}$ ) soils in intermediate zone at vegetative and seed maturity stage, respectively (Table 8). The dry root biomass varied to a certain extent in different soils which may be attributed to favourable soil conditions, high organic matter of the soil, climate and topography in respective areas (Siribel et al., 2004).

The alkaloid content of Withania somnifera was higher $(0.0962$ and $0.1827 \%)$ in Jammu soils followed by $(0.0956$ and
$0.1775 \%)$ Chatha and (0.0872 and $0.0899 \%)$ Kathua in sub tropical zone and least was recorded in Rajouri (0.0698 and $0.0818 \%$ ) in intermediate zone at vegetative and seed maturity stages (Table 8). Further, the root alkaloids increased with increase in age i.e., at seed maturity stage. This result may be attributed in part to the increase in dry root and plant biomass which resulted from thickening of cell walls. Also, it may be due to plant senescence, which resulted in decrease in number of young and fall of older leaves.

The study revealed that the change in soil properties, root and alkaloid yield was found maximum at $T_{10}$ - treatment and was more prominent in rhizosphere soil in all treatments. Application of organics improved soil health, biomass and percent alkaloid content $(\%)$ in Withania somnifera. Through this study it is recommended that subtropical zone is highly suitable for the cultivation of this high value medicinal crop.

\section{Acknowledgments}

Authors are grateful to the Director, Centre for Biodiversity Studies, Baba Ghulam, Shah Badshah University, Rajouri for providing seedlings and Director, IIIM, CSIR Jammu for analysis of alkaloids. The Head, Division of Soil Sciences and Agriculture Chemistry, SKUAST-J, Chatha is acknowledged for providing necessary facilities to carry out this research work.

\section{References}

Atiyeh, R.M., C.A. Edward, S. Subler and J.D. Metzger: Pig manure, vermicompost as a component of a horticultural beeding plant medium. Effect on physico-chemical properties and plant growth. 
Biores. Tech., 78, 11-20 (2001).

Babu, M.V.S., M.C. Reddy, A. Subramanyam and D. Balaguravaih: Effect of integrated use of organic and inorganic fertilizers on soil properties and yield of sugarcane. J. Ind. Soc. Soil Sci., 55, 161$166(2007)$

Bajpai, R.K., S. Chitale, S.K. Upadhyaya and J.S. Urkurkar: Long term studies on soil physico-chemical properties and productivity of rice-wheat system as influenced by integrated nutrient management in Inceptisol of Chattisgarh. J. Ind. Soc. Soil Sci.,54, 24-29 (2006).

Bakker, P.A.H.M., R.L. Berendsen, R.F. Doornbos, P.C.A. Wintermans and C.M.J, Pieterse: The rhizosphere revisited: Root microbiomics. Front. Pl. Sci., 4, 1-7 (2013).

Balyan, J.K., P. Singh, L.K. Jain and M.L. Jat: Maize (Zea mays L.) productivity in response to integrated nutrient management in Southern Rajasthan. Curr. Agric., 30, 63-65 (2006)

Barber S.A.: Influence of the plant root on ion movement in soil. In: The plant root and its environment (Ed.: E.W. Carson) Univ. Press Virginia, Charlottesville. p. 691 (1974).

Bargaz, A., K. Lyamlouli, M. Chtouki, Y. Zeroual and D. Dhiba: Soil microbial resources for improving fertilizers efficiency in an integrated plant nutrient management System. Front Microbiol., 9, 1606 (2018).

Brink, S.C.: Unlocking the secrets of the rhizosphere. Trends Plant Sci., 21, 169-170(2016)

Chaudhary, S.R., J. Kumar, A.P. Chaudhary and B.B. Basak: Organic nutrient sources influence yield and quality of ashwagandha (Withania somnifera), and soil biochemical properties. Agrochimica, 61, 221-236 (2017).

Dar, P.A., L.R. Singh, M.A. Kamal and T.A. Dar: Unique medicinal properties of Withania somnifera: Phytochemical constituents and protein component. Curr. Pharm. Des., 22, 535-540 (2016).

Das, K., R. Dang and T.N. Shivananda: Influence of bio-fertilizers on the availability of nutrients ( $N, P$ and $K$ ) in soil in relation to growth and yield of Stevia rebaudiana grown in South India. Int. J. App. Res. Nat. Pro., 1, 20-24 (2008)

Dessaux, Y., C. Grandclément and D. Faure: Engineering the rhizosphere. Trends Plant Sci., 21, 266-278 (2016).

Erktan, A., M.L. McCormack and C. Roumet: Frontiers in root ecology: Recent advances and future challenges. Plant and Soil, 424, 1-9 (2018)

Fageria, N.K. and L.F. Stone: Physical, Chemical and biological changes in the rhizosphere and nutrient availability. J. Plant Nut., 29, 1327-1356 (2006).

Gupta, A.P., R.K. Verma, H.O. Misra and M.M. Gupta: Quantitative determination of withaferin-A different plant parts of Withinia sominifera by TLC densitornetry. J. Med. Arom. Plant Sci., 18, 788790 (1996)

Kang, G.S., V. Beri, O.P. Rupra and B.S. Sidhu: A new index to assess soil quality and sustainability of wheat based cropping systems. Biol. Fertil. Soils., 41, 389-398 (2005).

Karthikeyan, B., M.M. Joe, C.A. Jaleel and M.D. Sundaram: Effect of root inoculation with plant growth promoting rhizobacteria on plant growth, alkaloid content and nutrient control of Catharanthus Roseus (L). Nat. Croat., 19, 205-212(2010).

Khan, K., U. Pankaj, S.K. Verma, A.K. Gupta, R.P. Singh and R.K. Verma: Bio-inoculants and vermicompost influence on yield, quality of Andrographis paniculata, and soil properties. Ind. Crops Prod., 70, 404-409 (2015).

Khajuria, R.K., K.A. Suri, R.K. Gupta and G.N. Qazi: Separation identification and quantification of selected withanolides in plant extracts of Withania somnifera by HPLC-UV(DAD) - Positive ion electrospray ionisation-mass spectrometry. J. Sep. Sci., 2, 541-6 (2004).

Krutika, J., S.D. Tavhare, K. Panara, P. Kumar and K. Nishteswar: Studies of Ashwagandha (Withania somnifera Dunal). Int. J. Pharm. Biol. Arch., 7, 1-11 (2016).

Kumpawat, B.S. and M.L. Jat: Profitable and energy efficient integrated nutrient management practices for maize-mustard cropping system in Southern Rajasthan. Curr. Agr., 29, 97-102 (2005).

Kumar, B., R.K. Gupta and A.L. Bhandari: Soil fertility changes after long term application of organic manures and crop residues under ricewheat system. J. Ind. Soc. Soil Sci., 56, 80-85 (2008).

Kumar, V., A.S. Solanki and S. Sharma: Yield and economics of Withania somnifera influenced by dual inoculation of Azotobacter chroococcum and Pseudomonas putida. Turk. J. Biol., 33, 219-223 (2009)

Kumpawat, B.S. and M.L. Jat: Profitable and energy efficient integrated nutrient management practices for maize - mustard cropping system in Southern Rajasthan. Curr. Agr., 29, 97-102 (2005).

Mekki, A., F. Aloui and S. Sayadi: Influence of biowaste compost amendment on soil organic carbon storage under arid climate. J. Air Waste Manag. Assoc., 69,867-877 (2017).

Pareek, N. and B.L. Yadav: Effect of organic manure on soil physicochemical properties, soil microbial biomass and yield of mustard under irrigation of different residual sodium carbonate waters. J. Ind. Soc. Soil Sci., 69, 336-342 (2011).

Pathak, S.K., S B. Singh, R.N. Jha and R.P. Sharma: Effect of nutrient management on nutrient uptake and changes in soil fertility in maize (Zea mays) wheat (Triticum aestivum) cropping system. Ind. J.Agron., 50, 269-273 (2005).

Ramakrishnaiah, G. and T. Vijaya: Influence of VAM Fungi, Azotobacter species and PSB on soil phosphatase activity and nutrients (N, P, $\mathrm{K}, \mathrm{Cu}, \mathrm{Zn}, \mathrm{Fe}$ and $\mathrm{Mn}$ ) status in the rhizosphere of Stevia rebaudiana (Bert.) plants. Am. J. Plant Sci., 4, 443-1447 (2013).

Rovira, A.D. and C.B. Davies: Biology of the rhizosphere. In: The Plant Root and its Environment (Ed.: E.W. Carson) Univ. Press Virginia, Charlottesville, pp. 153-204 (1974).

Siribel, A.A. M.A., G.M. El-Hassan, A.E. Modutair and M.A.R. Abdalla: Effect of soil type plant age on performance of two morphological types of Catharanthes roseus grown in Sudan. J. Med. Aro. PI. Sci., 26,17-23(2004).

Shinde, B.N. and A.J. Patil: Use of phosphorus solubilizing cultures and rock phosphate on phosphorus availability to wheat in black calcareous soil. Curr. Res. Rep., 1, 105-106 (1985).

Subashchand and D. Ram: Effect of integrated nutrient management on yield and nutrient use efficiency in mustard. Ind. J. Fert., 3, 51-54 (2007).

Tolanur, S.I. and V.P. Badanur: Changes in organic carbon, available N, P and $\mathrm{K}$ under integrated use of organic manure, green manure and fertilizer on sustaining productivity of pealmillet pigeonpea system and fertility of an Inceptisol. J. Ind. Soc. Soil Sci., 5, 37-41(2003).

Vasant, M., J.C. Ganiger, M.B. Mathad, H.B. Madalageri, , N.S. Babalad, K.S. Hebsur and B.Y. Nirmala: Effect of organics on the physicochemical properties of soil after bell pepper cropping under open field condition. Karnataka J. Agr. Sci., 25, 479-484(2012).

Umadevi, M., R. Rajeswari, R.C. Sharmila, S. Selvavenkadesh, R. Pushpa, K.P Sampath Kumar and D. Bhowmik: Traditional and medicinal uses of Withania somnifera. Pharmacol. Innov. 1, 102$110(2012)$ 